\title{
FLEDGLING NORTHERN HAWK-OWL AT WEYAKWIN, SASKATCHEWAN
}

RON JENSEN, 1027 King Crescent, Saskatoon, Saskatchewan. S7K 0N9

In the area between Weyakwin townsite and Montreal Lake the forest cover near the road had been removed by fire. Jack Pine now grows on the high ground but the low, wet areas were either not burned or had not advanced in the regeneration process.

On the evening of 22 June 1987 an unusual sound was heard from the road. Presently an owl flew nearby and alighted on a dead snag. It was a Northern Hawk-Owl.

The owl flew off but soon reappeared carrying something in its beak. It landed in a dead tree, uttered a rasping screech and a second owl appeared. They both made the screeching sounds, bobbed heads and exchanged the food. The recipient carried the prey in a flight path parallel to the roadway into a low, wet area where it was lost in the cover.

On 28 June Jonathan Matthews and the author searched the wet undulating area with a jumble of burned deadfall, live willows and tamarack where the owl had disappeared. After a half hour the owls were aroused and their reactions to our movements were used to aid in locating one of the young, which was photographed.

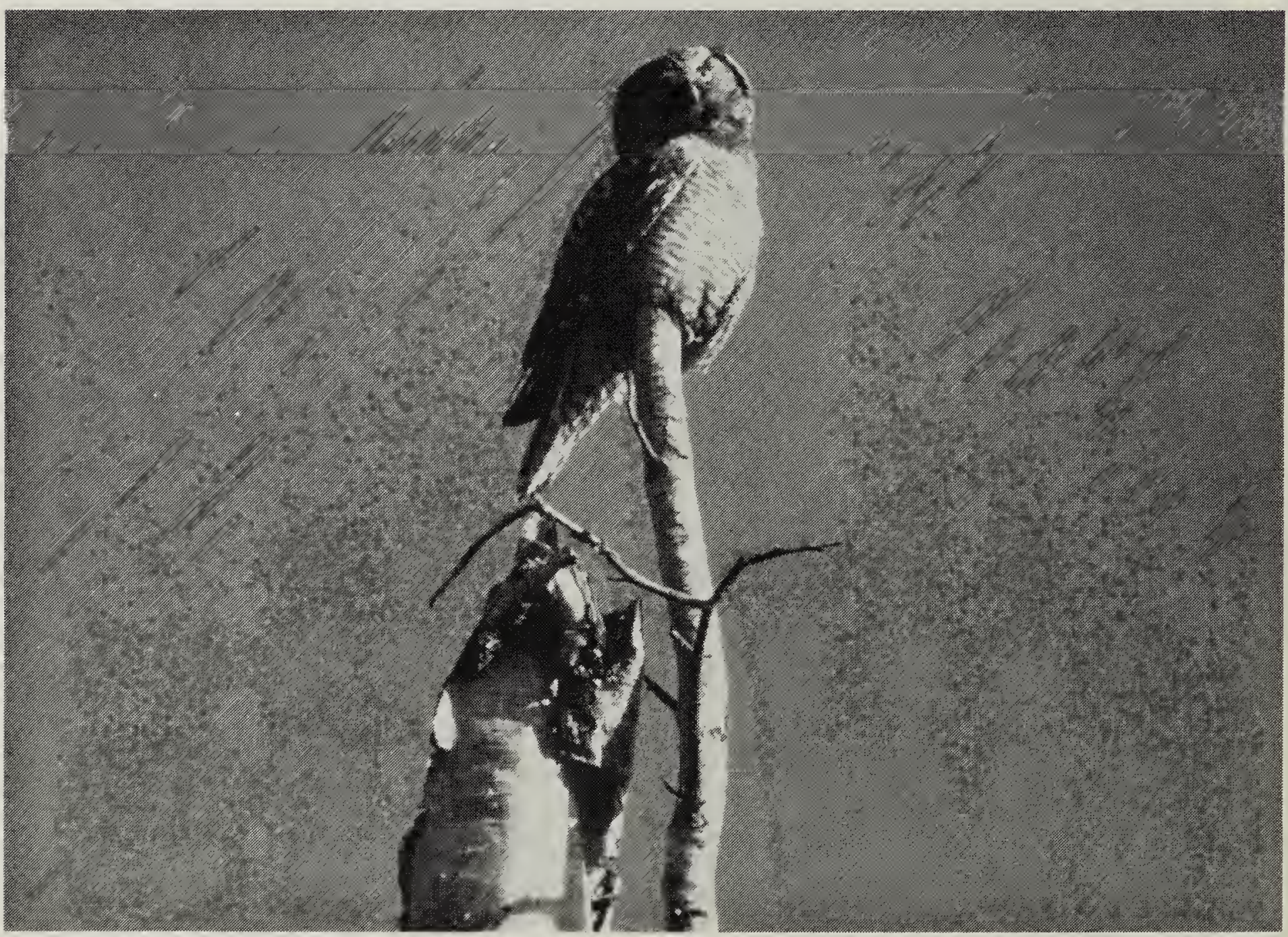




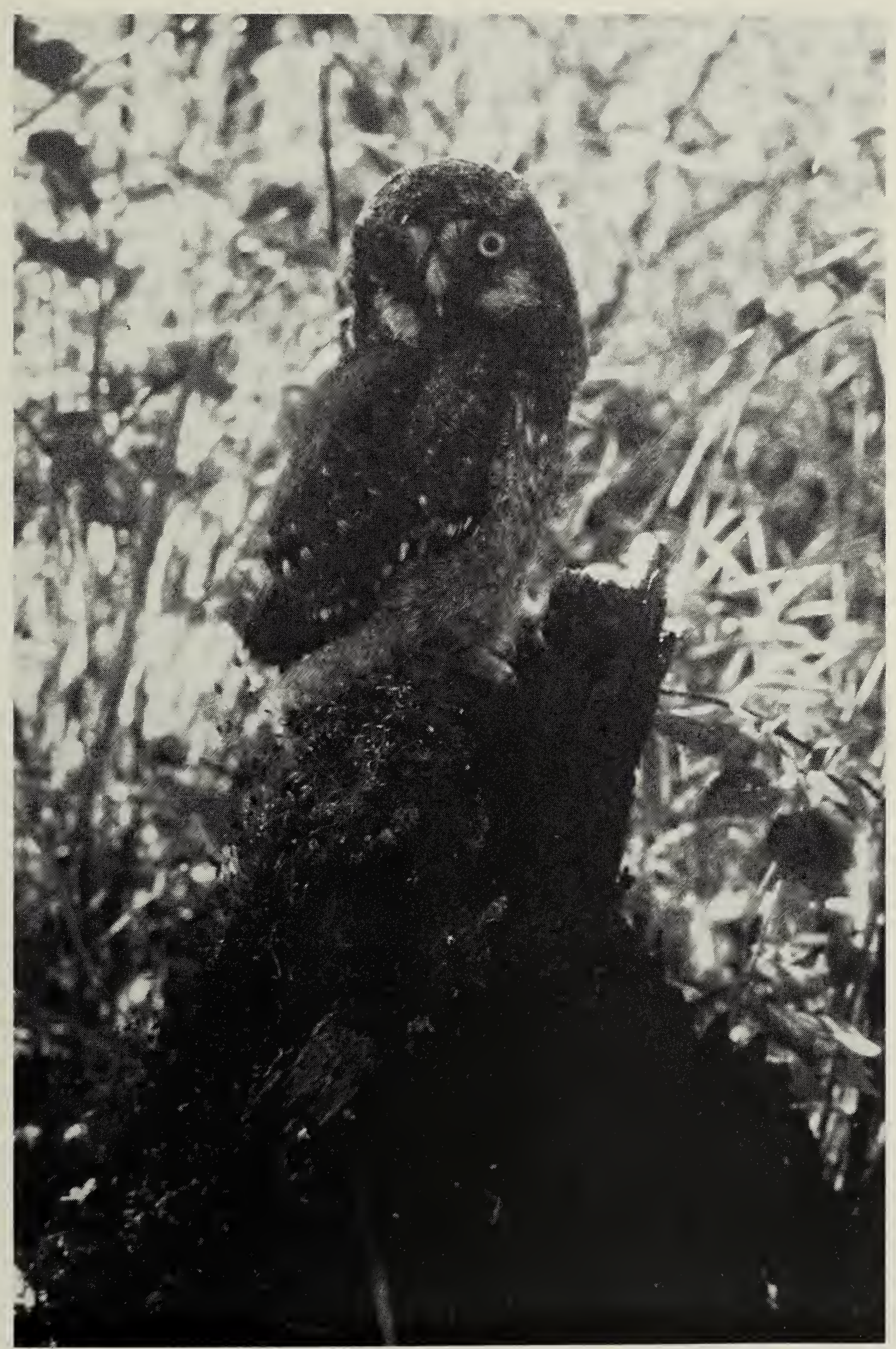

Young Northern Hawk Owl, Montreal L.

Ron Jensen 